\title{
Interaksi Sosial Tradisi Bagurau Saluang Dendang Minangkabau di Sumatera Barat
}

\author{
Rustim ${ }^{1}$, Wisma Nugraha Ch.R., dan G.R. Lono L. Simatupang \\ Program Studi Pengkajian Seni Pertunjukan dan Seni Rupa \\ Sekolah Pascasarjana Universitas Gadjah Mada
}

\begin{abstract}
Social Interaction of Bagurau Saluang Dendang Minangkabau Tradition in West Sumatra. This study examines the performance communication of bagurau saluang tradition of Minangkabau as a socio-cultural contact and the identity of pagurau groups. Bagurau is a performance of saluang dendang tradition which involves pagurau groups to interact during the show. Therefore, the study applies communication performances approach which is divided into two forms, namely communication as a process and communication as the production of meaning. The research data based on performance texts in form of dendang, pantun and pagurau interaction behavior in performance and its relation with the socio-cultural reality of the local community. The research finding shows three patterns of interaction between performer and the pagurau, namely: one-way interaction (between the pendendang with one group of pagaurau), two-ways interaction (between the pendendang with two groups of pagurau) and multi-ways interaction (between pendendang with many groups of pagurau). Finally, the interaction in this performance is a medium of pagurau social contact to integrate that serves as a buffer of the continuity of the performance and the realization of group existence among pagurau communita.
\end{abstract}

Keywords: interaction; bagurau; saluang dendang

\begin{abstract}
ABSTRAK
Penelitian ini mengkaji tentang komunikasi pertunjukan tradisi bagurau saluang dendang di Minangkabau sebagai kontak sosio-kultural dan identitas kelompok pagurau. Bagurau merupakan pertunjukan seni tradisi saluang dendang yang melibatkan kelompok-kelompok pagurau untuk berinteraksi dalam pertunjukan. Pendekatan yang digunakan adalah komunikasi pertunjukan yang terbagi pada dua bentuk, yakni komunikasi sebagai proses dan komunikasi sebagai produksi makna. Data penelitian bersumber dari teks-teks pertunjukan berupa dendang, pantun-pantun, dan perilaku interaksi pagurau dalam pertunjukan dan keterhubungannya dengan realitas sosio-kultural masyarakat setempat. Hasil penelitian menunjukkan bahwa ada tiga pola interaksi antara penyaji dan pagurau pertunjukan, yaitu satu arah (interaksi antara pendendang dengan satu kelompok pagaurau), dua arah (interaksi antara pendendang dengan antar dua kelompok pagurau) dan multi arah (interaksi pendendang dengan banyak kelompok pagurau). Interaksi dalam pertunjukan ini sebagai wadah kontak sosial pagurau untuk berintegrasi yang berfungsi sebagai penyangga kelangsungan pertunjukan dan perwujudan eksistensi kelompok antar komunita pagurau.
\end{abstract}

Kata kunci: interaksi; bagurau; saluang dendang

\section{Pendahuluan}

Pertunjukan kesenian tradisi bagurau saluang dendang di Minangkabau merupakan salah satu bentuk kesenian yang melibatkan partisipasi dan interaksi pagurau (pecandu seni bagurau) dalam pertunjukannya. Pagurau memiliki posisi penting sebagai unsur pertunjukan, sehingga paguran tidak dapat diposisikan sebagai penonton biasa. Dalam konteks ini, pertunjukan tradisi bagurau

\footnotetext{
1 Alamat korespondensi: Institut Seni Indonesia Padangpanjang. Jln. Bahder Johan Padangpanjang.
} Hp.: 08126764535.E-mail: rustim_satie@yahoo.com. 
saluang dendang tidaklah sama dengan bentuk pertunjukan saluang dendang yang dihadirkan pada kegiatan upacara adat, acara keagamaan, dan pesta perkawinan.

Perbedaan terletak pada konteks dan tujuan pertunjukan, orang yang terlibat, tempat pertunjukan, dan bentuk interaksi pertunjukan. Konteks pertunjukan bagurau saluang dendang dalam rangka alek nagari yang bertujuan untuk mencari dana pembangunan dan kegiatan sosial. Pertunjukan ini dihadiri oleh kelompokkelompok pagurau yang ada pada suatu nagari yang melaksanakan pertunjukan, dan dapat juga melibatkan kelompok pagurau dari nagarinagari lainnya. Bentuk pertunjukan seperti ini menjadi hidup ketika sebuah pertunjukan disangga partisipan penonton (pagurau) untuk berkomunikasi dan berinteraksi dalam memaknai budaya lokal masyarakat setempat.

Fokus penelitian membahas tentang mobilitas kelompok pagurau pertunjukan bagurau saluang dendang dalam membangun hidupnya interaksi pertunjukan. Dalam perspektif komunikasi ada dua kategori komunikasi yakni; pertama, komunikasi sebagai proses (transmisi teks) yang menitik beratkan pada cara pengirim dan penerima mengkonstruksi pesan (encode) dan menerjemahkannya (decode) melalui saluran dan media komunikasi. Kedua, komunikasi sebagai produksi dan pertukaran makna (interaksi teks) yang mempersoalkan cara pesan atau teks berinteraksi dengan orang-orang dalam rangka menghasikan makna (Fiske, 2010).

Jembatan kedua kategori komunikasi tersebut dikembangkan oleh Jakobson yang menyebutkan ada 6 faktor yang mesti ada yang memungkinkan terjadinya komunikasi, antara lain pengirim, penerima, konteks, pesan, kontak dan kode (Fiske, 2010). Hadirnya saluang dendang sebagai pengirim pesan dan pagurau (kelompok penonton) sebagai penerima pesan akan memicu munculnya interaktivitas, ketika penyaji dan penonton memiliki pengalaman dan makna yang berbeda terhadap tema budaya yang disajikan sebagai pesan. Menurut Sugiharto (2013) musik adalah pengalaman, di dalamnya berpadu unsur perasaan, imajinasi, gagasan, komunikasi, dan kerangka pikir budaya. Dalam konteks inilah aktivitas bagurau hadir sebagai wadah berinterkasi untuk memproduksi dan pertukaran makna melalui pantun-pantun yang didendangkan sebagai media komunikasi pertunjukan.

Dalam pertunjukan bagurau saluang dendang yang menjadi inti utamanya adalah keterlibatan dan partisipasi penonton dalam pertunjukan. Antara kelompok-kelompok pecandu bagurau dengan simbol-simbol yang diusungnya untuk berinteraksi dengan anak dendang (pendendang) dengan menggunakan pantun-pantun sebagai medianya. Simarmata (2017) menyatakan pantun merupakan salah satu jenis puisi lama yang sangat luas dikenal dalam bahasa-bahasa Nusantara. Pantun berasal dari kata patuntun dalam bahasa Minangkabau yang berarti "petuntun". Pantun melatih seseorang berfikir tentang makna kata sebelum berujar. Ia juga melatih orang berfikir asosiatif, bahwa suatu kata bisa memiliki kaitan dengan kata yang lain. Menurut Asril (2018),

creating pantun spontaneously requires a high level of skill and is an indicator of the singer's ability to compose a text or lyrics quickly and also appropriate to the target audience. Spontaneous pantun is always needed, especially at the time of a performance (bagurau). Inspiration for the opening lyrics and the main lyrics of the pantun generally comes from the atmosphere of the performance and from the audience.

Isi pantun sebagai material pertunjukan merupakan hasil aksentuasi ekspresi anak dendang terhadap realitas sosio-kultural. Anak dendang dan para pagurau dan antar kelompok pagurau berinteraksi untuk merespon makna pantun secara beragam berdasarkan realitas dan pengalaman sosiokultural masyarakat setempat dan penyempurnaan makna-makna tersebut terjadi saat proses interaksi pertunjukan berlangsung.

\section{Fenomena Bagurau dalam Pertunjukan Saluang Dendang}

Bagurau (bersenda gurau) sebagai konsep sosial diangkat ke dalam bentuk pertunjukan kesenian tradisi saluang dendang, sehingga konsep bagurau merupakan tradisi yang khas dalam 
pertunjukan saluang dendang. Bagurau sebagai konsep sosial awalnya sebuah aktivitas sehari-hari sekelompok orang untuk melakukan kegiatan tertentu, dan tempat tertentu yang disepakati bersama, dengan suasana penuh keakraban untuk mengisi waktu luang dan menghibur diri. Menurut Bahar (2015) kehadiran seni pertunjukan secara sistemik terbentuk oleh konteks upacara dan atau tradisi dalam bingkai budaya lokal masyarakat bersangkutan. Seni merupakan bagian independen dari bagian lain yang membentuk upacara budaya atau suatu tradisi. Sukmawati (2008) berpendapat bahwa bagurau muncul dari tradisi lisan (oral tradition) yaitu tradisi bercakap-cakap atau bercerita dalam suasana yang akrab. Sindir-sindiran melalui ungkapan-ungkapan bahasa yang tajam merupakan kebiasaan yang sudah umum dan dikenal luas dalam masyarakat Minangkabau. Rustiyanti (2014) juga menyatakan bahwa bagurau dapat diartikan sebagai suatu konsep masyarakat Minangkabau untuk menyebut suatu kegiatan sekelompok orang yang bermain, berkelakar, atau menceritakan sesuatu di antara sesama dalam suasana keakraban.

Aktivitas ini dilakukan umumnya kaum lakilaki sebagai pengisi waktu dan pelepas lelah pada malam hari menjelang tidur setelah seharian bekerja di sawah dan ladang. Sebagai masyarakat dengan mata pencaharian yang bertumpu pada pertanian, bagurau dijadikan pilihan sebagai wadah untuk bersosialisasi, berinteraksi, dan berintegrasi, serta berekspresi dengan cara-cara kelompok. Bagurau dalam pertunjukan saluang dendang, berintikan aktivitas dan perilaku kelompok pagurau dalam menyaksikan pertunjukan saluang dendang.

Selama pertunjukan berlangsung, kelompok pagurau dapat mengikutinya dengan leluasa dan

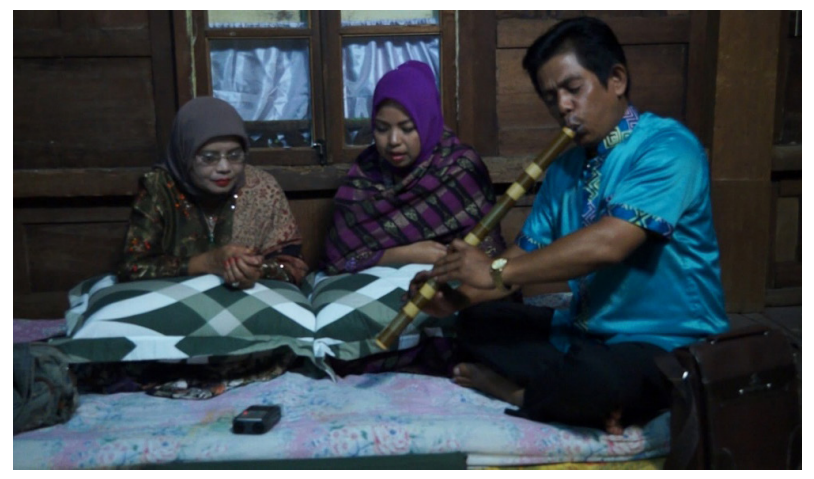

Gambar 1. Formasi pertunjukan Saluang Dendang Tradisi. (Foto: Rustim) sedikit lebih bebas karena hampir tidak ada aturan tertentu dalam menyaksikan pertunjukan tersebut. Perilaku dan aktivitas orang yang terlibat dalam pertunjukan berlangsung dengan bebas, seperti datang terlambat, pindah-pindah tempat duduk, makan-makan dan minum-minum, berjualan, duduk di sembarang tempat, merokok, main kartu remi dan domino, berbicara, bersorak, dan pulang ke rumah dapat kapan saja, dan kegiatan lainnya sepanjang tidak menggangu jalannya pertunjukan.

Bagurau saluang dendang yang berlangsung sepanjang malam dari pukul 21.00 sampai dengan 04.00 Wib dini hari, menghadirkan seorang tukang saluang (peniup saluang), dan 2 sampai 3 orang anak dendang (pendendang), dan satu orang janang ("moderator") pertunjukan. Salah satu yang cukup penting dari kesenian ini adalah bahwa bagurau saluang dendang sebagai wahana berinteraksi dan berintegrasi. Dalam berinteraksi, ada dua hal yang dapat dilihat dalam pertunjukan tradisi bagurau saluang dendang ini, yaitu: Pertama, pertunjukan sebagai proses komunikasi, yaitu adanya pengiriman dan penerimaan pesan melalui gurindam dan pantun-pantun yang didendangkan. Kedua, pertunjukan sebagai komunikasi memproduk dan pertukaran makna, yaitu interaksi berlangsung untuk pembentukan makna-makna dan saling dipertukarkan antara orang yang terlibat dalam pertunjukan.

Interaksi ditandai dengan adanya pesan yang disampaikan, pengirim dan penerima pesan, sehingga dalam prosesnya terdapat stimulasi pesan yang dapat direspon oleh siapa saja yang hadir dalam pertunjukan, baik anak dendang maupun kelompok pagurau. Pantun dendang adalah salah satu sumber yang nyata untuk memahami interelasi antara human behavior dan musik. Oleh karena itu, dalam pertunjukan tersebut telah terjadi proses interaksi sosial yang mengarah pada elaborasi kultural. Tema-tema dendang dikembangkan dan berhubungan dengan realitas sosio-kultural dan perilaku pagurau yang terlibat dalam pertunjukan. Tema-tema tersebut berisikan pesan-pesan yang berasal dari artikulasi anak dendang atas fenomena sosial dan budaya yang ditujukan kepada pagurau, baik individu maupun kelompok, sehingga para pagurau dapat memberikan respon-respon tertentu 
untuk menanggapi pesan-pesan tersebut. Menurut Sedyawati (1980) ada dua bentuk seni pertunjukan, yaitu seni sebagai tontonan dan seni sebagai pengalaman bersama. Seni pertunjukan tradisional di Indonesia cenderung dalam bentuk yang kedua, yaitu pelaku bisa menyindir penonton, di mana bisa terjadi percakapan antara pemain dan penonton, bahkan juga di mana pemain sewaktu-waktu bisa masuk di antara penonton, dan penonton sekali waktu ikut bermain.

Bentuk respon yang disampaikan dalam tradisi bagurau saluang dendang sangat beragam, seperti permintaan jenis dendang tertentu, mengirim gurindam atau pantun balasan secara tertulis, memperpanjang sajian pantun, mengalihkan tema dendang, dan bersorak sebagai dukungan serta letupan-letupan kata-kata tertentu sebagai tanda tidak setuju atau sindiran. Kenyataan bentuk pertunjukan ini, mengindikasikan ada tema-tema dengan pesan-pesan tertentu yang dikomunikasikan, sehingga kelompok-kelompok pagurau dapat memberikan tanggapan terhadap pesan-pesan tersebut.

Pantun yang didendangkan secara musikal dalam pertunjukan bagurau saluang dendang, memiliki simbol-simbol sosio-kultural yang diekspresikan secara estetik. Simbolisasi dalam tradisi bagurau saluang dendang bukanlah simbolsimbol yang mewakili dirinya, akan tetapi memiliki relasi dengan sosio-kultural masyarakat setempat. Musik tidak dapat eksis hanya oleh, dari, dan untuk dirinya sendiri, tetapi harus selalu ada manusia yang berbuat sesuatu untuk memproduknya. Ritawati (2018) menyatakan,

each double or pantun stanza has (1) complete and perfect unity of mind, (2) has symbols that are in accordance with the norms and values of the local community: (3) and there is a meaning relationship between the shadow and the intent.

Hal ini sejalan dengan yang disebutkan Sriyanto (2012), bahwa yang harus dimiliki oleh pemain saluang dendang adalah pemahaman tentang capaian kualitas estetik saluang dendang, kemampuan mengekspresikan berbagai jenis dan judul dendang, dan etika atau perilaku sosial pertunjukan.
Dalam tradisi bagurau saluang dendang, partisipasi dan keterlibatan pagurau menjadi suatu keharusan, karena dalam pertunjukan tersebut peranan kelompok-kelompok pagurau menjadi penyangga keberhasilan pertunjukan. Partisipasi pertunjukan diwujudkan melalui interaksi antar pagurau dengan anak dendang yang mengusung simbol-simbol realitas sosio-kultural kehidupan sehari-hari sebagai bagian dari tema-tema interaksi pertunjukan. Perhatian akan tertuju pada tematema sajian dan tindakan perilaku pagurau potensial dan aktif berkomunikasi dan berinteraksi dalam pertunjukan. Dengan demikian, dalam tradisi bagurau saluang dendang telah terjadi proses komunikasi dan interaksi untuk pembentukan makna-makna pesan berdasarkan simbol-simbol sosio-kultural masyarakat.

Interaksi sosial melalui pantun dalam pertunjukannya memberikan peluang yang cukup besar kepada pagurau untuk memberikan tafsiran-tafsiran pesan berdasarkan pengalaman mereka masing-masing secara berulang-ulang pada lagu yang sama, sehingga dialektika makna ini memotivasi para pagurau untuk senantiasa aktif dan terus mengembangkannya dari satu pertunjukan ke pertunjukan yang lainnya. Fraser (2013) menyebutkan,

a dendang is identified by its melody not by its text, because texts change for a given melody from one artist and performance to the next. Strophic in form, a melodic cycle is repeated while the choice of text and number of times the cycle is repeated varies according to the circumstances.

Hal yang sama juga dinyatakan Sastra (2018) yaitu, traditional performance of saluang-dendang is in strophic form in which a particular melody is sung over and over again by the vocalist with different pantun texts. These texts are created spontaneously with themes that are chosen to suit the purpose and situation of the performance. Hence, the ability to create pantunis an essential skill for the dendangartist to possess in the logogenic musical style of traditional saluang-dendang, in order to build a dynamic atmosphere in the performance. 
Hubungan teks dengan konteks pertunjukan tradisi bagurau saluang dendang dalam interaksi sosial memiliki relasi dan saling mempengarui. Teks tidak hanya dipandang sebagai sebuah pesan dengan ekspresi estetis, akan tetapi suatu ekspresi perasaan, kesadaran dan bahkan pandangan hidup (ideologi) manusia. Santosa (2002) berpendapat bahwa pertunjukan tidak hanya dipandang sebagai medium untuk menyampaikan dan menerima pesan estetis, namun juga sebagai sesuatu yang mengandung pesan lain seperti halnya terjadi pada bentuk komunikasi lain. Keyakinan inilah yang melandasi bahwa interaksi sosial dalam seni pertunjukan secara tidak langsung dipengaruhi oleh sistem pengetahuan, sosial budaya, ekonomi, dan pandangan hidup masyarakat setempat.

Interaksi yang berlangsung selama pertunjukan tidak hanya menyangkut stimulus dan respon pesan, tetapi interaksi tersebut terbingkai dalam pengalaman estetik pelakunya. Responsif penonton yang muncul dalam pertunjukan bagurau saluang dendang sangat ditentukan oleh keberhasilan interaksi yang dilakukan anak dendang pada saat pertunjukan. Salah satu realitas yang dapat diamati adalah teks pantun yang dinyanyikan sarat dengan bahasa kiasan (sastra puitik). Kepekaan seorang pendendang dalam menangkap tujuan pesan dari kelompok pagurau dan merespon dengan pilihan pantun yang tepat, akan membangun kualitas interaksi pertunjukan dengan penontonnya. Kualitas anak dendang tidak hanya pada penguasaan pantun dan menangkap pesan, tetapi juga kepekaan membaca situasi pertunjukan dan reaksi penonton saat pertunjukan berlangsung.

\section{Interaksi Sosial Pertunjukan}

Bagurau saluang dendang sebagai sebuah bentuk interaksi sosial komunitas pagurau mensyaratkan pertunjukan tradisi bagurau sebagai kontak sosial dan keterlibatan dalam interaksi sebagai saluran komunikasi pertunjukan. Interaksi sosial dalam pertunjukan tradisi bagurau bertujuan untuk mengintegrasikan individu dan kelompok dalam komunitas pagurau sebagai proses adaptasi budaya. Dalam proses interaksi sosial secara simbolis orang mengomunikasikan makna kepada orang lain yang terlibat. Orang lain menafsirkan simbol-simbol tersebut dan mengarahkan respon tindakan berdasarkan penafsiran mereka. Dengan kata lain, dalam interaksi sosial, aktor terlibat dalam proses pengaruh mempengaruhi. Interaksi sosial dalam pertunjukan tradisi bagurau saluang dendang, dilandasi dengan pola-pola kelompok sebagai bentuk manifestasi kekerabatan masyarakat Minangkabau yang bertumpu pada berbagai bentuk jaringan kelompok pasukuan dalam adat, kelompok kongsi dalam pertanian, kelompok sasaran dalam kesenian, serta lapau sebagai konsep pergaulan sosial masyarakat Minangkabau.

Interaksi sosial dalam pertunjukannya memberikan peluang yang cukup besar kepada pagurau untuk memberikan tafsiran-tafsiran pesan berdasarkan pengalaman mereka masing-masing, sehingga dialektika makna ini memotivasi para pagurau untuk senantiasa aktif dan terus mengembangkannya dari satu pertunjukan ke pertunjukan yang lainnya. Dendang sebagai materi dasar pertunjukan bagurau saluang dendang juga membentuk pertunjukan lainnya yaitu Randai. Randai merupakan teater tradisi Minangkabau yang salah satu unsur adalah dendang selain dialog dan galombang (semacam gerakan tarian yang berakar pada gerak silat Minangkabau). Ketiga unsur randai ini juga berinteraksi dan membangun dialektika pertunjukan dalam penceritaan $k a b a$ (cerita rakyat) dalam pertunjukan randai. Wendy (2014) menyebutkan dendang merupakan bekal dan kepekaan emosional melalui jalinan lirik dan irama yang bersumber dari pantun, gurindam dan kutipan petatah petitih.

Berdasarkan tinjauan di atas, setidaknya ada empat bentuk dan pola kelompok dalam kehidupan budaya, ekonomi, sosial, dan kesenian yang mendasari pada pembentukan kelompokdalam bagurau saluang dendang. Keempat bentuk dan pola tersebut dihubungkan berdasarkan ciri-ciri pembentukan, perilaku, dan tujuan yang diusung secara kolektif. Navis (1984) berpendapat bahwa sesuai dengan ajaran alam terkembang jadi guru yang menjadi sumber falsafahnya, orang Minangkabau membentuk masyarakat yang komunalistik, baik dalam kediaman (tempat tinggal), sosial, maupun dalam usaha. Artinya, mereka itu hidup berkelompok. Dalam kehidupan dan lingkungan masyarakat 
petani. Irianto (2017) menegaskan bahwa bertolak dari sikap mengutamakan kedamaian dan ketentraman, sejumlah aturan, norma, serta bentuk ekspresi kesenian tradisional diwariskan ke generasi berikutnya melalui tradisi-tradisi untuk menopang dan mempertahankan kolektivitas sosial.

Tujuan utama dari kelompok-kelompok tersebut adalah membangun jaringan persaudaraan yang bersifat kekeluargaan untuk mewujudkan tujuan bersama. Sekalipun terjadi perubahan diberbagai sektor kehidupan masyarakat akibat perubahan sosial, budaya, dan ekonomi, namun nilai-nilai kebersamaan kelompok masih terpelihara dengan baik, terutama dalam kesenian tradisional. Hal ini dapat dilihat dari indikasi dukungan kelompok pagurau tidak hanya bersifat internal nagari, tetapi dukungan itu datang dari banyak nagari yang mengarah pada terbentuknya komunitas dalam pertunjukan kesenian tradisi.

Bagurau saluang dendang sebagai salah satu genre musik tradisi Minangkabau memiliki simbolsimbol tertentu yang dapat diurai berdasarkan fungsi komunikasi. Unsur-unsur bagurau saluang dendang terletak pada perilaku kelompok-kelompok penonton, interaksi komunikasi pemain dengan penonton, dan tema-tema yang dibangun dalam pertunjukan. Ketiga unsur ini merupakan gagasan pokok dalam kajian bagurau saluang dendang yang berfungsi sebagai komunikasi sosial budaya. Dalam kaitan ini bagurau saluang dendang berwujud dalam ekspresi musikal sebagai kerangka pertunjukan yang berfungsi untuk berinteraksi.

\section{Komunikasi Pertunjukan sebagai Proses}

Interaksi sosial dipandang sebagai proses yang berhubungan dengan cara pengirim dan penerima

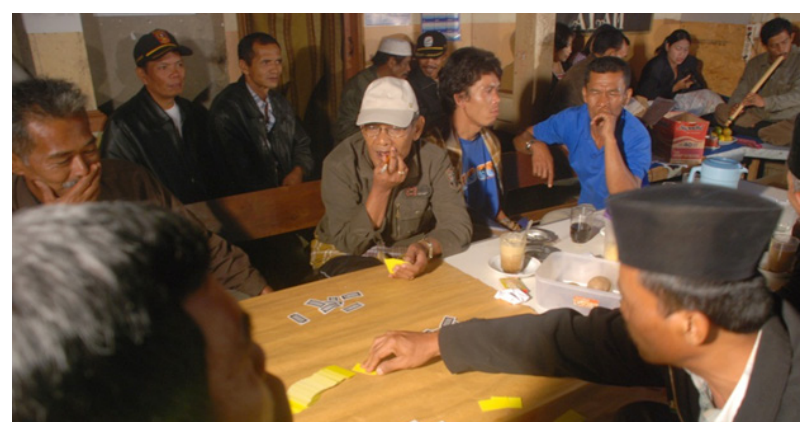

Gambar 2. Suasana interaksi Pagurau dalam pertunjukan. (Foto: Rustim) mengkonstruksi pesan dan menerjemahkannya serta cara transmiter menggunakan saluran dan media komunikasi (Fiske, 2010). Untuk melihat bagurau saluang dendang sebagai proses komunikasi, mengacu pada model tindakan komunikasi yang dikembangkan Jakobson.

Berdasarkan skema pada gambar 3 dapat ditelusuri posisi teks dan konteks situasi komunikasi dalam bagurau saluang dendang. Pengirim (adresser) dan penerima (adressee) disamakan dengan anak dendang dan pagurau; pesan merujuk pada pantun dendang; kontak identik dengan peristiwa bagurau; konteks mengacu pada pemaknaan sosio-kultural; dan kode dilihat dari tema tradisi dalam interaksi. Oleh karena itu ada tiga pola interaksi yang berkembang dalam pertunjukan tradisi bagurau saluang dendang, yakni interaksi berpola satu arah, dua arah, dan multi arah.

Keenam "konstituen" pada gambar 4 memiliki fungsi komunikatif yang berlainan; seperti fungsi emotif (konstruksi pesan bersifat emotif), fungsi konatif (dampak pesan terhadap penerima), fungsi pengacuan (konstruksi pesan sebagai informasi), fungsi puitik (relasi pesan dengan pesan itu sendiri), fungsi fatik (saluran kumunikasi tetap terbuka), dan fungsi metalingual atau identifikasi kode yang digunakan (Danesi, 2010). Keenam fungsi ini menduduki tempat yang sama dalam

\begin{tabular}{ccc} 
& $\begin{array}{c}\text { Konteks } \\
\text { Pesan } \\
\text { Pengirim } \\
\text { (adresser })\end{array}$ & $\begin{array}{l}\text { Penerima } \\
\text { (adressee })\end{array}$ \\
\cline { 2 - 2 } & $\begin{array}{c}\text { Kontak } \\
\text { Kode }\end{array}$ &
\end{tabular}

Gambar 3. Model komunikasi yang dikembangkan Jakobson.

Pola 1 (satu arah) Pola 2 (dua arah) Pola 3 (multi arah)

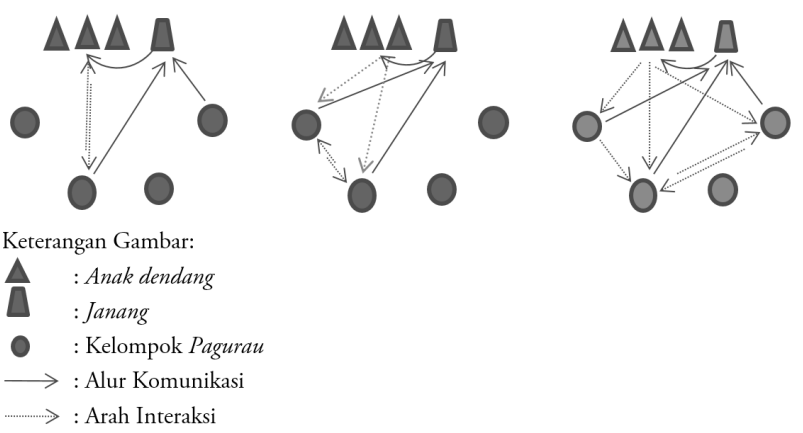

Gambar 4. pola interaksi pertunjukan tradisi bagurau saluang dendang. (Rustim) 
modelnya seperti faktor-faktor yang diacu dalam tindakan komunikasi di atas, dapat digambarkan seperti pada gambar 5 .

Fungsi-fungsi ini dalam bagurau saluang dendang dapat diungkap, bahwa fungsi emotif berupa ekspresi dari aksentuasi anak dendang dan pagurau terhadap pengalaman sosio-kultural, pada konteks ini anak dendang dan pagurau berperan dalam dua fungsi, yakni sebagai adresser sekaligus adressee berbentuk siklus melingkar. Pesan-pesan yang dibangun dalam interaksi bersifat metafor yang berkombinasi antara ekspresi musikal (dendang) dan ekspresi non-musikal (pantun). Pesan-pesan dalam bentuk pantun-pantun memiliki fungsi referensial terhadap kehidupan sosio-kultural seharihari mereka, dengan menggusung simbol-simbol tema tradisi sebagai kode komunikasi (metalingual), serta menjadikan peristiwa bagurau sebagai

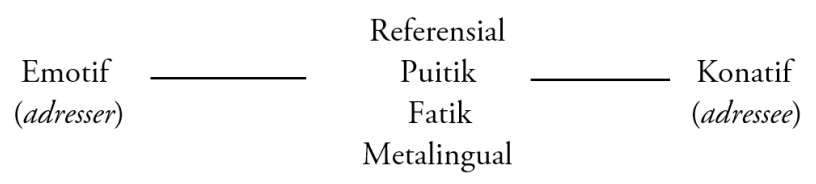

Gambar 5. Model konstituen Danesi. saluran yang terbuka untuk berinteraksi. Menurut Santosa (2018), walaupun tumbuh, berkembang, dan disajikan dalam kesederhanaan, namun terdapat hal-hal yang menarik dari pertunjukan kesenian tradisonal di Minangkabau, yaitu sifat komunikatifnya dengan penonton. Penonton secara bersama-sama dan secara langsung bisa ikut terlibat dalam suasana pertunjukan. Saat pertunjukan berlangsung tidak terlihat jurang pemisah antara yang satu dengan yang lain, semuanya membaur menjadi satu dalam kebersamaan

Komunikasi dan interaksi antara anak dendang dengan kelompok-kelompok pagurau berlangsung sangat akrab, karena dalam pertunjukan formasi tempat duduk antara penyaji dan pagurau hampir tidak ada jarak (jarak sosial), sehingga pagurau lebih leluasa untuk berinteraksi dan berkomunikasi dengan anak dendang atau antar kelompok pagurau. Keberhasilan pertunjukan sangat ditentukan oleh kepiawaian anak dendang dalam mengeksplorasi tema dan ekspresi dendang serta kemampuannya berinteraksi menurut keinginan dan selera para pagurau.

Tabel 1. Teks-teks interaksi bertema baburu babi (berburu babi) antara pagurau dan anak dendang dalam memproduksi dan pertukaran makna.

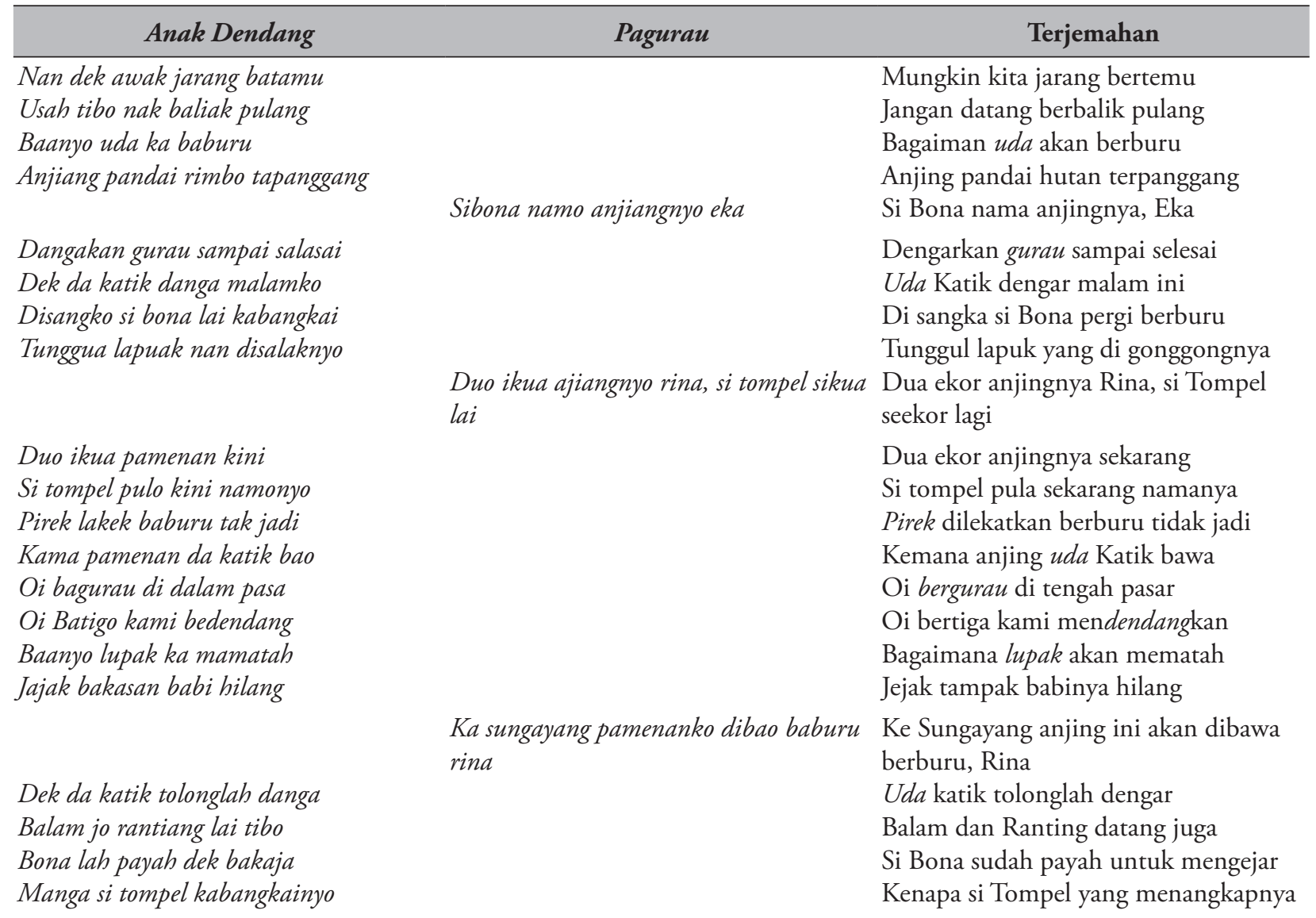


Oi bagurau samalam kini

Dek da katik jo kawan-kawan

Dima niak nan kamanjadi

Dek kanduang ganggam balapehkan

Jo da katik denai lah tahu

Hatinyo kareh-kareh karah

Da katik tasabuik urang paburu

Bakaja lai kabangkai indak

Takuik bana da katik ka itam

Tangah malam ba topi juo

Da katik bamain pisau tajam

Denai lah luko dek kileknyo

Dek da katik danga malamko

Malam kini lainyo datang

Disabuik bana apo kagunonyo

Uda lah arek di tangan urang

Oi badendang kami batigo

Dek da katik tolong simakkan

Nyampangko guyah satahunko

Elok kini udah lapebkan

Eloklah kito ka sungai patai

Bia si bona nak kasinan pulo

Asa jo uda katik niaik ka sampai

Agak sahari di kayai juo

Buru babi lagunyo kini

Dek da katik danga samalamko

Nan dek denai sabana dalam hati

Dek da katik buktikan pulo

Dek rang banyak tolonglah danga

Dek pak wali baitu pulo

Caliak da katik nan banyak aka

Ka induak-induak tagak manyaleknyo

Kok iyo da katik sabana sayang

Mintak izinlah nan kanan tuo

Elok pagi denai antakan pulang

Disungai patai salamonyo

Elok sibona uda tinggakan

Baitu bana pasan samalamko

Kalau iyo niak balangsuangkan

Marapeklah duduak di siko

Ibo bana da katik jo si bona

Oi ka denai badutoi sajo

Lah diganjua suruik salangkah

Pado isuak jo aia mato

Kok baniaik ka sungai patai

Rang suayan bana pambayannyo
Oi bergurau semalam kini

Uda Katik dengan kawan-kawan

Di mana niat akan menjadi

Bagi kandung genggam dilepaskan

Uda Katik saya sudah tahu

Hatinya keras-keras karak

Uda Katik tersebut orang pemburu

Mengejar ada menangkap tidak

Indak batanyo hati ketekko do eka, inyo sabana urang pagurau

Bukan bertanya hati kecil ini, Eka. Saya

benar-benar orang pemburu

Takut benar $u d a$ Katik akan hitam

Tengah malam memakai topi juga

Uda Katik bermain pisau tajam

Denai telah luka kena kilatnya

Topiko bana pamanibnyo

Topi ini sebagai pemanis

Uda Katik dengarkan malam kini

Malam ini dia ada datang

Disebut benar apa gunanya

Uda sudah erat di tangan orang

Sanabu lai lah, agak guyah kini ko eka Tambah pantunnya, agak goyah sekarang hati ini, Eka

Oi berdendang kami bertiga

Uda Katik tolong di pahami

Nyampang goyah hati setahun ini

Sebaiknya sekarang uda lepaskan

Sebaiknya kita ke Sungai Patai

Biar si Bona kesana juga

Asal dengan $u d a$ Katik niat disampaikan

Walaupun sehari diupayakan juga

Lai sabana kato hati eka, lai kamandi aia angek di sungai Patai

Apakah benar dari hati kecil, Eka?,

bisakah mandi dengan air hangat di sungai Patai

Berburu babi dendangnya sekarang

Uda Katik dengar semalam ini

Bagi saya benar-benar dalam hati

Bagi uda Katik buktikan juga

Bagi orang banyak tolonglah dengar

Kepada pak Wali begitu juga

Lihat $u d a$ Katik yang banyak akal

Di tempat ibu-ibu berdirinya

Itu tanda orang sedang malas selera

Jika benar $u d a$ Katik benar sayang

Minta izinlah sama istri tua

Sebaiknya saya antarkan pulang

Di sungai Patai $u d a$ Katik selamanya

Sebaiknya si Bona uda tinggalkan

Begitu pesan saya malam ini

Jika niat akan dilangsungkan

Merapatlah duduk ke tempat ini

Kalau kabatinggakan anjiang bialah ndak jadi ka sungai patai batalkan ke sungai Patai

Sayang benar $u d a$ Katik sama si Bona

Kenapa saya didustai juga

Sudah disurutkan kaki selangkah

Daripada esok berderai air mata

Jika berniat ke Sungai Patai

Orang Suayan jadi besannya 
Kalimat-kalimat pantun di atas berisikan sindiran dalam bentuk kiasan atas simbolsimbol peristiwa buru babi yang dikembangkan dalam konteks perilaku pemburu babi, terutama kehadiran, hubungan, dan tujuan interaksinya dengan pendendang saat pertunjukan berlangsung. Oleh karenanya, nilai estetik pertunjukan dapat dicapai dengan intensitas dan kualitas interaksi yang dilakukan dalam mengusung tema yang dikomunikasikan. Putra (2017) menyebutkan sindir-kias dalam hal ini merupakan produk budaya dan sekaligus produk historis masyarakat Minangkabau. Nilai-nilai yang muncul dalam penyampaian sindir-kias adalah sesuatu yang sangat subjektif. Penyampaian sindiran dalam tradisi suku Minang merupakan ekspresi jiwa yang diperuntukkan bagi tercapainya atau terjadinya suatu nilai.

Keberhasilan pertunjukan bagurau saluang dendang sangat tergantung pada kapasitas interaksi dan tingkat keterlibatan kelompok-kelompok pagurau dalam pertunjukan. Kapasitas interaksi dan tingkat keterlibatan pagurau bertumpu pada kemampuan anak dendang dalam membangun stimulus melalui kualitas suara, penguasaan dendang dan pantun, serta spontanitas eksplorasi pantun yang relevan dengan situasi pertunjukan saat itu. Pantun-pantun yang didendangkan sebagai materi utama sajian pertunjukan merujuk kepada tema-tema tradisi sosial sebagai segmen-segmen interaksi pertunjukan.

Simbol-simbol tema tradisi yang diangkat selama pertunjukan, baik oleh pendendang dan pagurau terus berinteraksi satu sama lain dalam kerangka penyempurnaan makna sosio-kultural yang disimbolkan. Menurut Duvignaud (2009) sikap terhadap seni melibatkan suatu hubungan antara tanda yang dimunculkan perorangan dan oleh sekelompok manusia. Tanda-tanda ekspresi hanya memperoleh arti jika apa yang seniman tandai mengacu pada sesuatu yang menjadi penting dan mempunyai nilai simbolik untuk kelompok yang menerima dan disepakatinya.

\section{Komunikasi Pertunjukan sebagai Produksi Makna}

Komunikasi sebagai produk dan pertukaran makna yang dimaksud adalah cara pesan-pesan atau teks berinteraksi dengan orang-orang dalam rangka menghasilkan makna; yakni berkenaan dengan peran teks dalam kebudayaan. Dalam konteks ini, pesan tidak lagi dipandang sebagai pesan itu sendiri, tetapi makna apa yang didapatkan dari pesan tersebut. Berarti pesan telah memproduk makna baru di luar makna pesan itu sendiri sesuai konteks situasi pesan difungsikan. Makna musik pada dasarnya terkategori dalam tiga jenis, yakni; (1) Makna musik diperoleh dari apa yang diungkapkan atau disebut dengan simbolis atau makna referensial, (2) makna musik, disebut juga dengan estetika, non-referensial, atau mutlak, dan (3) makna musik lebih erat kaitannya dengan adaptasi budaya daripada ekspresi budaya (Kaemmer, n.d.).

Teks sebagai media produksi makna harus dikaitkan dengan situasi tertentu, karena pemaknaan teks akan berubah bila situasinya juga berubah. Konsep ini merupakan upaya untuk menafsirkan teks dalam konteks sosial tertentu, yaitu lingkungan terjadinya pertukaran makna. Dalam bagurau saluang dendang sumber pesan dapat juga berasal dari kelompok pagurau, judul dendang, pantun dendang, dan perilaku pagurau. Sumber pesan yang berasal dari kelompok pagurau, misalnya Balam jo Rantiang (Balam dan Ranting). Balam adalah nama sejenis burung dengan segala sifatnya dan ranting adalah ranting kayu tempat burung hinggap yang sewaktu-waktu bisa patah. Sumber pesan yang berasal dari judul dendang seperti Balam jo Rantiang, pesan yang dikandungnya menyimbolkan "tempat persinggahan" yang sifatnya sementara, ibarat balam dengan ranting, ranting ke tempat hinggap sementara. Pantun-pantun dendang juga merupakan sumber pesan yang dikembangkan secara metafora, sedangkan tindakan dan perilaku pagurau pada saat pertunjukan merupakan 
sumber-sumber pesan dalam pertunjukan yang dikembangkan dalam kontek situasi tertentu.

Misalnya dendang baburu babi (berburu babi), dalam pertunjukan makna simbol baburu babi tidak lagi mengacu pada makna referensinya, tetapi telah dimaknai baru sesuai konteks situasi dan pengalaman orang terlibat dalam interaksi pertunjukan. Setiap anak dendang melalui pantunpantun dendang di atas, memberikan aksentuasi baburu babi dengan simbolisasi yang berbedabeda. Perbedaan tersebut jelas dipengaruhi oleh pengalamannya masing-masing terhadap tandatanda sosio-kultural. Ada yang menandai sebagai status seseorang (lihat: teks-teks interaksi), seperti uda Katik tasabuik urang paburu (uda Katik ternama orang pemburu), ada yang memberi simbol persaingan, seperti bakaja lai kabangkai indak (sering memburu tapi jarang menangkap buruan), atau simbol percintaan, seperti uda Katik bamain jo pisau tajam, denailah luko dek kileknyo (uda katik suka bermain pisau tajam, telah luka saya dengan kilatnya), dan simbol kearifan seseorang, seperti diganjua suruik salangkah, pado isuak jo aia mato (melangkah surut selangkah, dari pada kemudian meneteskan air mata), dan lain sebagainya.

Eksplorasi pantun sebagai teks dendang dibangun secara spontan di atas melodi yang sama secara berulang-ulang. Menurut Sunarto (2007), setiap teks memiliki sejarahnya sendiri; seringkali sebuah teks tunggal memiliki melodimelodi terhubung yang berbeda. Di lain pihak, sebuah melodi tunggal bisa cukup untuk beberapa teks. Pantun sebagai materi utama untuk menyampaikan pesan merupakan aksentuasi anak dendang terhadap realitas sosial dan budaya,

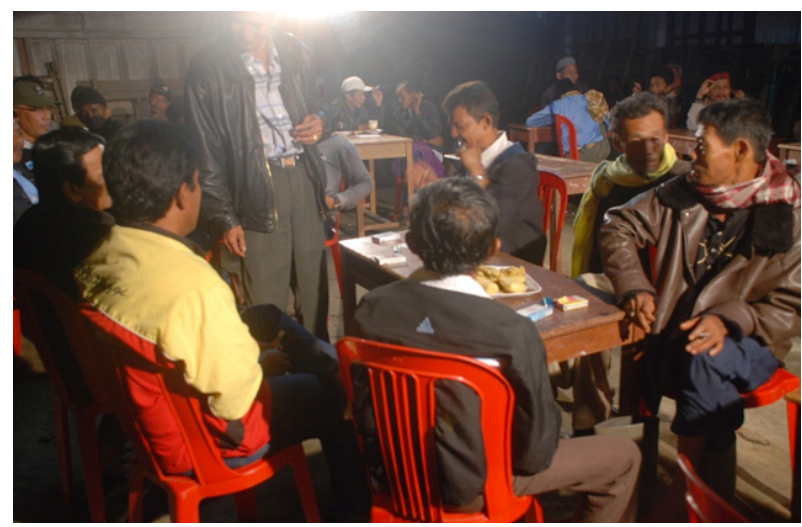

Gambar 6. Suasana interaksi kelompok-kelompok Pagurau dalam pertunjukan. (Foto: Rustim) sehingga pantun dapat disebut sebagai simbol untuk memaknai sosio-kultural masyarakatnya. Blacking (1974) berpendapat If music serves as a sign or symbol of different kinds of human experience, its performance may help to channel the feelings of listeners in certain directions. Arah tertentu dimaksud adalah aksentuasi seseorang terhadap tanda yang diekspresikan dengan cara yang spesifik. Teks yang dibuat produser atau oleh penerima, atau keduaduanya, tidak akan pernah memberikan kepastian bahwa jaringan interpretan (tafsiran) terhadap suatu bentuk tertentu akan selalu sama bagi setiap pihak yang terlibat dalam proses dimensi poetic dan estetis (Ganap, 2003).

Partisipasi pagurau dalam pertunjukan tidak hanya membangun suasana pertunjukan itu sendiri, tetapi juga interaksi komunikasi yang terjadi dalam kerangka menemukan maknamakna baru dalam realitas sosio-kultural mereka. Menurut Rustiyanti (2014), komunikasi dalam suatu pertunjukan akan memberikan beberapa keuntungan, di antaranya dapat memperoleh ilmu dan informasi, di mana terjadi suatu pertukaran informasi antar individu melalui sistem lambang, tanda, dan tingkah laku. Tema yang diusung dalam pertunjukan menjadi materi interaksi pagurau satu dengan lainnya dan melahirkan makna yang beragam baik bagi individu maupun kelompok sesuai pengalaman mereka terhadap realitas sosio-kultural. Keberagaman makna inilah yang menjadi substansi pertunjukan tradisi bagurau saluang dendang dibanding keseragaman dengan makna tunggal, sehingga inti interaksi simbolik itu bertumpu pada perbedaan interpretasi sesuai pengalaman mereka masing-masing.

\section{Bagurau sebagai Kontak Sosio-kultural}

Bagurau sebagai salah satu aktivitas yang ada dalam seni pertunjukan tradisi Minangkabau, mempunyai dampak yang cukup besar terhadap pola-pola interaksi sosial masyarakat. Bagurau adalah wadah kontak sosial masyarakat pagurau menjadi bentuk dan pola yang khas (tetap dan berulang-ulang) dalam tindakan komunikasi sosial. Interaksi sosial tersebut memiliki hubungan dengan pemolaan integrasi sosial masyarakat, baik 
dalam kelompok kecil, maupun komunitas yang membentuk identitas tertentu, khususnya dalam pertunjukan kesenian tradisi.

Integrasi dipahami sebagai upaya untuk menyatukan pribadi-pribadi pada aktivitas tertentu, integrasi yang berlangsung bisa bersifat kelompokkelompok kecil, komunitas tertentu, dan kelompok sosial masyarakat yang lebih besar. Sedangkan integrasi sosio-kultural dalam bagurau merupakan upaya penyatuan pribadi-pribadi atau kelompok dalam suatu aktivitas artistik yang berlandaskan pengalaman sosio-kultural. Wadiyo (2006), menyatakan pertunjukan musik bisa menjadi gegap gempita karena adanya interaksi sosial antara penonton dengan kelompok pemain musik yang tampil di panggung yang membawakan lagu kesukaan mayoritas penonton. Begitu juga para penonton merespon musik dan merespon ekspresi para penonton lain yang akhirnya saling pengaruh mempengaruhi menjadikan suasana menjadi histeris dan atau riang ataupun haru. Dalam aktivitas bagurau misalnya, pada setiap segmen-segmen pertunjukan selalu mengarah kepada simbol-simbol tertentu, baik simbol yang ada pada individu, maupun kelompok pagurau yang terlibat dalam pertunjukan. Seorang pagurau yang memakai topi morris, kepala botak, rambut panjang, memakai baju merah, tubuh kerdil atau besar, atau inisial nama-nama individu dan nama-nama kelompok pagurau akan menjadi bahan pantun bagi anak dendang sebagai tema-tema dalam berinteraksi.

Penyingkapan sandi berarti membaca kodekode budaya yang dijadikan material untuk berintegrasi. Dalam aktivitas pertunjukan tradisi bagurau saluang dendang misalnya, bertujuan untuk menghibur diri, berekspresi, berinteraksi dan walaupun pada saat situasi tertentu terbuka peluang untuk terjadinya disintegrasi antar sesama kelompok pagurau. Pola seperti ini dalam bahasa lokal disebut juga sebagai bagaluik (interaktif) yang tidak hanya muncul dalam bagurau saluang dendang tetapi juga dalam talempong pacik. Sastra (2015) menyebutkan bagaluik merupakan kesan estetika musikal dalam permainan ketika terjadi interaksi antar pemain sesuai perannya masingmasing. Partisipasi pagaurau dalam pertunjukan pada situasi tertentu juga terjadi perselisihan dalam arti perbedaan pendapat dalam memaknai isi dan tujuan pantun yang disajikan atau merasa dilecehkan. Perselisihan ini akan berlangsung dalam waktu tertentu dengan cara mendominasi jalannya pertunjukan melalui penyampaian pesan yang saling berpotongan antar kelompok pagurau (disebut bajoak: interaksi antar pagurau). Bajoak ini juga bagian pertunjukan yang memicu disintegrasi antar kelompok pagurau dan inisiatif penyelesaian bisa muncul dari anak dendang, janang atau kelompok pagurau lain yang tidak terlibat dalam perselisihan tersebut.

Kelompok pagurau juga merupakan simbolsimbol integrasi sosio-kultural, misalnya, kelompok pagurau Lapua Randah, Ampek Sajalan, Pantau Tarusan, Lintas Kapau dan Pauh Sakato yang terbentuk atas dasar pergaulan sosial di lapau kopi, atau kelompok Taruna Baru, Putra Utama, Campago Sarojo, Pacah Manih dan Bungo Saka yang terbentuk atas dasar ekonomi atau persamaan profesi, dan begitu juga dengan kelompok saondoh gadang, salayang pandang, tikam tuo, dan Balam jo Rantiang yang mendasari pembentukan kelompoknya pada akar budaya. Nama-nama tersebut lebih dikenali mereka sebagai penjelasan nama-nama orang yang ada dalam kelompok tersebut dalam kontak sosial keseharian mereka.

Kontak sosial menjadi suatu wadah terciptanya hubungan antar pribadi dan kelompok untuk mengekpesikan diri dalam mencapai tujuan bersama, yakni menghibur diri. Bagurau adalah salah satu bentuk kontak sosial yang dibangun untuk berekspresi dan bertujuan untuk kepentingan integrasi sosial dan adaptasi budaya melalui seni pertunjukan. Proses integrasi dan adaptasi ini dicapai dalam bentuk interaksi sosial dalam wilayah yang khusus dengan dukungan individu dan kelompok tertentu pula, dalam upaya meningkatkan jaringan kelompok pagurau dan komunitas pagurau sebagai penyangga dan penjaga keberlangsungan tradisi bagurau saluang dendang di Minangkabau.

\section{Kelompok dan Identitas}

Penjelasan istilah kelompok dan identitas dalam sosio-kultural masyarakat, diperlukan 
Tabel 2. Partisipan pertunjukan Bagurau Saluang Dendang.

\begin{tabular}{|c|c|c|c|}
\hline \multicolumn{2}{|c|}{ Kelompok Penyaji } & \multicolumn{2}{|c|}{ Komunitas Pagurau } \\
\hline Nama dan Profesi & Asal Daerah & Nama Kelompok & Asal Daerah \\
\hline 1. Pakiah Iref (Tukang saluang) & Nagari Baso & 1. Pantau Tarusan & Kamang \\
\hline 2. Upik Malai (Anak dendang) & Nagari Kayu Tanam & 2. Birudu Indah & Pasanehan \\
\hline 3. Eka (Anak dendang) & Nagari Sungai Patai & 3. Lintas Kapau & Kamang \\
\hline 4. Reni (Anak dendang) & Nagari Cingkariang & 4. Buyuang Rimbo & Lasi \\
\hline 5. Ike (Anak dendang) & Nagari Baso & 5. Campago Sarojo & Sarojo \\
\hline 6. Sutan Sinaro (Tukang orgen) & Bukittinggi & 6. Tanjuang Raya & Maninjau \\
\hline \multirow[t]{3}{*}{ 7. Uncu Lasi (Janang) } & Nagari Lasi & 7. Ampek Sajalan & - \\
\hline & & 8. Tarantang Jaya & Padangpanjang \\
\hline & & 9. Pauah Sakato & Kamang \\
\hline \multicolumn{2}{|c|}{ Judul Dendang yang Disajikan } & 10. Putra Utama & Canduang \\
\hline \multicolumn{2}{|c|}{ 1. Singglang } & 11. Gurun Saiyo & Bk. Batabuah \\
\hline \multicolumn{2}{|l|}{ 2. Ratok Pasaman } & 12. Umbua-Umbua & Biaro \\
\hline \multicolumn{2}{|l|}{ 3. Larek di Nagari } & 13. Baringin Sonsang & Lasi \\
\hline \multicolumn{2}{|c|}{ 4. Talempong Anam Koto } & 14. Putra Bungsu & Kubu Apa \\
\hline \multicolumn{2}{|c|}{ 5. Katitihan Danau } & 15.6810 & Lasi \\
\hline \multicolumn{2}{|l|}{ 6. Pak Wali } & 16. Pemuda Panca & Ampek Angkeh \\
\hline \multicolumn{2}{|l|}{ 7. Jablai (dangdut) } & 17. Pemuda Pakan & Perantau \\
\hline \multicolumn{2}{|l|}{ 8. Indang Cerenti } & 18. Harimau Putiah & Canduang \\
\hline \multicolumn{2}{|c|}{ 9. Ratok Pasaman } & 19. Taruna Baru & Bk. Batabuah \\
\hline \multicolumn{2}{|c|}{ 10. Sipatuang Ka Hinggok } & 20. Saondoh Gadang & Biaro \\
\hline \multicolumn{2}{|c|}{ 11. Bola (dangdut) } & 21. Salayang Pandang & Sitapuang \\
\hline \multicolumn{2}{|c|}{ 12. Bacinto dalam Mimpi } & 22. Pagurau Sonsang & Canduang \\
\hline \multicolumn{2}{|c|}{ 13. Balam jo Rantiang } & 23. Bilalang Tengkak & Kamang \\
\hline \multicolumn{2}{|c|}{ 14. Kasiah tak Sampai } & 24. Bungo Saka & Lasi \\
\hline \multicolumn{2}{|c|}{ 15. Tigo Bulan Cinto Tajalin } & 25. Katam Sirauik & Biaro \\
\hline \multicolumn{2}{|c|}{ 16. Pria Idaman (dangdut) } & 26. Campago Dumai & Perantau \\
\hline \multicolumn{2}{|c|}{ 17. Koto Tuo Caruak } & 27. Dua Saudara & Simarasok \\
\hline 18. Suayan Maik Ka & Irun & 28. Balam Jo rantiang & Padangpanjang \\
\hline 19. Jalu-Jalu & & 29. Elok Saraso & Pasar Lasi \\
\hline & & 30.007 & Bukik Batabuah \\
\hline & & 31. Rang Jolong Gd. & Baso \\
\hline & & 32.48 & Canduang \\
\hline & & 33. Lapau Randah & Pasar Lasi \\
\hline & & 34. Putra Saripado & Baso \\
\hline & & 35. Aji Lasi & Lasi \\
\hline & & 36. Mak Adang & Baso \\
\hline & & 37. Mak Pon & Canduang \\
\hline & & 38. Intan Nagari & Lasi \\
\hline & & 39. Efendi R.M. & Baso \\
\hline & & 40. Kanda & Biaro \\
\hline & & 41. Pak Wi & Biaro \\
\hline & & 42. Da Men & Baso \\
\hline & & 43. Bang Kabuik & Padang Luar \\
\hline & & 44. Oon & Gaduik \\
\hline & & 45. Mak Buik & Gaduik \\
\hline & & 46. Indra Safero & Ampek Angkek \\
\hline & & 47. Inyiak Bancah & Lasi \\
\hline & & 48. Datuk Rajo & Canduang \\
\hline & & 49. Datuak Maruhun & Padang Tarok \\
\hline & & 50. Datuak Bengke & Padang Tarok \\
\hline & & 51. Mak Apuak & Baso \\
\hline
\end{tabular}

Sumber: Hasil penelitian lapangan, 2017. 
kajian yang berhubungan dengan interaksi dan sifat hubungan sosial serta tujuan yang ingin dicapai dari interaksi tersebut. Kelompok dalam konteks pagurau merupakan sekelompok orang yang memiliki kesamaan kegemaran, baik dalam tindakan sosialnya maupun dalam tindakan kultural. Ikatan sosial dan budaya dalam kelompok ini dilandasi dengan ikatan masyarakat tradisional yang bersifat oral, homogen, kesamaan status, dan norma. Dengan demikian tujuan kelompok adalah pemenuhan kebutuhan sosio-kultural, seperti suku (bidang adat), kongsi (bidang ekonomi) lapau (bidang sosial) dan sasaran (bidang kesenian). Kelompok-kelompok tersebut menjadi sarana kontak sosial dengan kondisi yang penuh keakraban dan persaudaraan, diikat dengan norma-norma sosial dan budaya setempat sebagai pembatas tindakan yang wajar dan dapat diterima secara kelompok, serta menjaga stabilitas kelompok sebagai bagian komunitas sosio-kultural.

Komunitas (community) merupakan bagian dari kelompok sosial (society), berada dalam wilayah kehidupan sosial yang ditandai oleh suatu derajat hubungan sosial tertentu. Dasar pembentukan komunitas masyarakat adalah lokalitas dan perasaan masyarakat setempat (community sentimen). Derajat hubungan tertentu ini dipahami sebagai adanya suatu kontak sosial yang diciptakan komunitas untuk melakukan aktivitas tertentu, dan dilandasi dengan nilai-nilai lokalitas masyarakat setempat. Sentimen komunitas meliputi bentuk seperasaan, sepenanggungan dan saling memerlukan. Komunitas menyiratkan berkumpulnya tujuan demi kemakmuran bersama, eksistensi norma-norma, dan bentuk solidaritas tertentu pada anggotaanggotanya.

Berdasarkan pola dasar pembentukan kelompok, tujuan, tindakan, norma dan upaya dalam menjaga stabilitas kelompok, pagurau dapat diposisikan sebagai komunitas (communita). Winangun (1990) merumuskan ciri-ciri komunitas adalah tak terbedakan, equalitarian, langsung ada, non-rasional, ekstensial, dan "antistruktur". Tak terbedakan dapat diidentifikasi dari "pagurau" dalam kelompoknya berada dalam posisi yang sama, tanpa adanya lapisan dan struktur sosial. Equalitarian, adanya kesamaan ciri pada setiap kelompok, seperti profesi kerja, kegemaran, teman sepergaulan, dan lain sebagainya. Langsung ada, hubungan kelompok pagurau yang dibentuk tanpa diperantarai orang lain. Non-rasional, hubungan lebih didominasi oleh fungsi intuisi dan perasaan (pola kekerabatan). Ekstensial, ditandai oleh adanya dan terpeliharanya eksistensi kelompok-kelompok dalam pagurauan. "Antistruktur" dikatakan Turner, bahwa aturan-aturan dan kategori-kategori yang ada dalam struktur sosial tidak berlaku untuk sementara.

Komunitas pagurau dapat dilihat dari kesatuan mereka dalam pertunjukan tradisi bagurau saluang dendang, oleh sebab itu komunitas ini tidak dapat dilihat dari satu kelompok pagurau saja. Melihat komunitas dalam bentuk pagurauan tentunya akan dapat menguraikan sifat tindakan sosial yang dilakukan, seperti berinteraksi untuk berintegrasi dalam pertunjukan dengan tujuan menjalin persaudaraan dan solidaritas pagurau, menjadikan bagurau sebagai kontak sosial yang efektif untuk berinteraksi dan beintegrasi, membangun integrasi sosial dalam kebersamaan, membangun nilai dan norma-norma baru yang positif bagi kehidupan sosial dan budaya, serta memperjuangkan tradisi bagurau sebagai bagian kebutuhan kehidupan mereka.

Dengan dukungan dan partisipasi kelompokkelompok pagurauyang menyangga berlangsungnya pertunjukan, tentunya bentuk pertunjukan tradisi bagurau saluang dendang berbeda dengan jenisjenis seni tradisi lain yang ada di Minangkabau. Perbedaan itu dapat dilihat dari adanya pecandu bagurau dalam bentuk kelompok, dibanding dengan pendukung yang ada dalam jenis kesenian lainnya yang bersifat individu. Banyak jenis kesenian tradisi yang berkembang di Sumatera Barat, namun bagurau saluang dendang satu-satunya bentuk pertunjukan yang memiliki kelompok-kelompok pendukung yang berada di berbagai nagari. Inilah yang dimaksud sebagai identitas pagurau dan tradisinya dalam bagurau saluang dendang. Simatupang (2013) berpendapat bahwa identitas pada dasarnya bersifat relasional, yakni hanya bisa ditentukan dalam perbandingannya dengan satuansatuan sosial lain. Penentuan identitas pada dasarnya merupakan tindakan pemilihan atas kesamaan dan 
perbedaan dalam continuum sosial tertentu, dan tindakan selektif sebagai pemilihan sejumlah kecil kesamaan dan mengabaikan sejumlah perbedaan. Kedua pendapat tersebut di atas, akan memperjelas penentuan kategori identitas sebuah pertunjukan kesenian tradisi.

Berdasarkan kategori seni sebagai tontonan dan seni sebagai pengalaman bersama, bagarau termasuk jenis pertunjukan seni sebagai pengalaman bersama yang ditandai dengan adanya interaksi dalam pertunjukannya. Posisi ini sekaligus dapat membedakan pertunjukan saluang dendang dengan bagurau saluang dendang. Dalam tradisinya, pertunjukan saluang dendang akan kehilangan jati dirinya sebagai pengalaman bersama ketika pagaran tidak menjadi unsur pelibat dalam pertunjukan. Perbedaan dalam pertunjukan tradisi bagurau saluang dendang dengan cara berkelompok menjadi dominasi tindakan pemilihan dan selektif dibanding kesamaan dengan bentuk kesenian lainnya. Bagurau merupakan identitas masyarakat pencinta seni bagurau, sehingga istilah bagurau hanya melekat pada pertunjukan saluang dendang, dibanding genre-genre kesenian tradisi Minangkabau lainnya. Pagurau adalah simbol pertunjukan tradisi bagurau saluang dendang, sehingga bagurau menjadi dirinya sendiri dalam sebuah pertunjukan kesenian tradisi yang ada di Minangkabau dan tidak ditemukan pada jenis kesenian lainnya di Sumatera Barat.

Dengan demikian, bagurau menjadi simbol identitas komunita pagurau yang ideal dalam pembentukan integrasi sosio-kultural melalui pertunjukan kesenian sebagai bagian proses adaptasi budaya. Budaya sebagai latar belakang ideologis dan nilai terhadap proses terjadinya interaksi sosial, menjadi landasan utama dalam pendayaan tafsiran makna simbolik pertunjukannya. Oleh karena itu, nilai budaya dalam proses, bentuk dan tujuan petunjukan kesenian tradisi, memiliki arti penting dalam memahami hubungan kodekode kesenian itu sendiri dengan sosio-kultural masyarakat setempat.

\section{Penutup}

Pertunjukan tradisi bagurau saluang dendang menjadi wadah kontak sosial untuk berekspresi dan berkomunikasi antar masyarakat pagurau. Selama pertunjukan, terjadi proses transformasi informasi, pengalaman, dan nilai-nilai baru dalam kehidupan sosio-kultural masyarakat sebagai bagian dari kebutuhan pengembangan pengetahuan, estetika kesenian dan etika pergaulan sosial. Kerjasama dan mobilitas sosial melalui pertunjukan semakin terkukuhkan dalam upaya untuk mengawal dan menyangga tatanan sosial dan pelestarian nilainilai budaya Minangkabau.

Dialektika dalam tradisi budaya Minangkabau merupakan hak bersama yang selalu dijunjung tinggi masyarakat dalam menjaga stabilitas sosial sebagai perwujudan masyarakat komunal. Pola tindakan dari berbagai arah dan kepentingan menjadi bagian penting sebagai bentuk dan ciri tatanan kehidupan bersama untuk mewujudkan eksistensi dan identitas kelompok berdasarkan kebebasan berfikir, berbicara dan berekspresi, terutama dalam pertunjukan bagurau saluang dendang.

Masyarakat Minangkabau yang bercirikan pola kehidupan berkelompok merupakan bagian dari kehidupan sosio-kultural masyarakat, sehingga tradisi ini mendorong lahirnya konsep keberagaman budaya masyarakat yang disebut sebagai adaik salingka nagari (adat selingkar nagari), dan menganggap kehidupan adalah keharmonisan atau perkawinan dari segala pasangan oposisi, sehingga pola berfikir masyarakat lebih bersifat dualistik, dikotomis, dan bipolaristis.

Pertunjukan tradisi bagurau saluang dendang sebagai suatu yang alamiah dalam simbolisasi kebudayaan masyarakat setempat dengan cara yang spesifik dan memandang pengalaman masyarakat disajikan dengan cara menurut dunianya sendiri. Pertunjukan tidak hanya sebagai wadah pemenuhan kebutuhan estetika, melainkan juga merupakan arena produksi makna dan pertukaran pengalaman dalam pemberdayaan nilai dan norma atas realitas sosio-kultural masyarakat Minangkabau. Bagurau saluang dendang sebagai produk kesenian yang sarat dengan makna simbolik merupakan kodifikasi kultural yang ditafsirkan dari berbagai dimensi sosial. Keberagaman makna yang timbul berdasarkan pengalaman para pagurau, menjadi tujuan utama dialektika interaksi pertunjukan dalam penyempurnaan akan makna simboliknya. 


\section{Kepustakaan}

Asril. (2018). Musical Ambivalence in The Performance of Saluang Orgen in West Sumatra. Arts and Design Studies Journal, (63), 31-40.

Bahar, M. (2015). Menyikapi Seni Pertunjukan Tradisional sebagai Media Pengembangan Bangsa. Mudra: Jurnal Seni Budaya, 30(1), 76-82.

Blacking, J. (1974). How Musical Is Man? Washington: University of Washington Press.

Danesi, M. (2010). Pesan, Tanda dan Makna: Buku Teks Dasar Mengenai Semiotika dan Teori Komunikasi. Terj. Evi Setyarini dan Lusi Lian Piantari. Yogyakarta: Jalasutra.

Duvignaud, J. (2009). Sosiologi Seni. Terj. Yupi Sundari, Nur Rochmat, dan Irma Rachminingsih. Bandung: Sunan Ambu Press.

Fiske, J. (2010). Cultural and Communication Studies: Sebuah Pengantar Paling Komprehensif. Terj. Yosal Iriantara dan Idi S. Ibrahim. Yogyakarta: Jalasutra.

Fraser, J. (2013). The Art of Grieving: West Sumatra's Worst Earthquake in Music Videos. Ethnomusicology Forum, 22(2), 129-159.

Ganap, V. (2003). "Kompleksitas Fakta Musikal", dalam Hermien Kusmayati (ed). Kembang Setaman: Persembahan Untuk Sang Maha Guru. Yogyakarta: BP ISI Yogyakarta.

Irianto, A. M. (2017). Kesenian Tradisional Sebagai Sarana Strategi Kebudayaan di Tengah Determinasi Teknologi Komunikasi. Nusa, 12(1), 90-100.

Kaemmer, J. E. (n.d.). Music in Human Life: Anthropological Perspectives on Music. Austin: University of Texas Press.

Navis, A. A. (1984). Alam Terkembang Jadi Guru: Adat dan Kebudayaan Minangkabau. Jakarta: Grafiti Pers.

Putra, A. A. (2017). Nilai Adaptif-Reflektif dalam Sindir-Kias sebagai Wujud Dinamika Kebudayaan Bahasa Minangkabau. Jurnal Filsafat, 27(1), 1-29.

Ritawati, T. (2018). Pantun in the text of Nyanyian Lagu Melayu Asli (NLMA), 18(1), 97-106.

Rustiyanti, S. (2014). Musik Internal dan Eksternal dalam Kesenian Randai. Resital: Jurnal Seni Pertunjukan, 15(2), 152-162.

Santosa. (2002). Aspek Komunikasi Perunjukan Gamelan. Makalah Seminar Internasional Seni Pertunjukan Indonesia, STSI Surakarta, 3-4 Juli.

Santosa, W. dan H. (2018). Peran Wanita dalam Seni Pertunjukan Tradisional Minangkabau di Tengah Perubahan Kehidupan Sosio Kultural Masyarakatnya. Kalangwan: Jurnal Seni Pertunjukan, 4(1), 63-70.

Sastra, A. I. (2015). Estetika Hegemoni Talempong Pacik di Sumatera Barat. Mudra: Jurnal Seni Budaya, 30(1), 18-35.

Sastra, A. I. (2018). Lareh Bodi Caniago: Power Systems and The Concept of Bagurau Saluang in A Study of Musical Aesthetics in Luhak Nan Tigo Minangkabau - Indonesia. Arts and Design Studies Journal, 64, 47-56.

Sedyawati, E. (1980). Pertumbuhan Seni Pertunjukan. Jakarta: Sinar Harapan.

Simarmata., M. I. R. dan T. (2017). Peran Tradisi Berbalas Pantun dalam Acara Pesta Perkawinan Pada Masyarakat Melayu di Tanjung Pura. Gondang: Jurnal Seni Dan Budaya, 1(2), 91-99.

Simatupang, L. L. (2013). Pergelaran: Sebuah Mozaik Peneitian Seni-Budaya. Yogyakarta: Jalasutra.

Sriyanto. (2012). Dimensi Estetika Pertunjukan Saluang Dendang di Minangkabau dalam Bagurau. Ekspresi Seni:Jurnal Ilmu Pengetahuan Dan Karya Seni, 14(2), 225-236.

Sugiharto, B. (2013). "Musik dan Misterinya" dalam Untuk Apa Seni. Bandung: Matahari.

Sukmawati, N. (2008). Bagurau Saluang dan Dendang Dalam Perspektif Perubahan Budaya Minangkabau. Jurnal: Forum Ilmu Sosial, 35(2), 158-170.

Sunarto. (2007). Components in Music-Culture. Harmonia: Jurnal Pengetahuan Dan Pemikiran Seni, 8(1), 1-9.

Wadiyo. (2006). Seni sebagai Sarana Interaksi Sosial. Harmonia: Jurnal Pengetahuan Dan Pemikiran Seni, 7(2), 1-9.

Wendy, H. (2014). Dramaturgi Teater Rakyat Randai di Minangkabau. Jurnal Kajian Seni, 
Resital Vol. 20 No. 1, April 2019

1(1), 32-47.

Winangun, W. (1990). Masyarakat Bebas Struktur:
Liminalitas dan Komunitas Menurut Victor Turner. Yogyakarta: Kanisius. 